\title{
頚椎脊柱管拡大術後の血腫評価における超音波検査の有用性
}

\author{
久留米大学整形外科 \\ 吉 松 弘喜・永 田見 生 \\ 後 藤 博 史・佐 藤 公 昭 \\ 安 藤 則 行
}

\section{Ultrasound for Valuation on Postoperative Hematoma in Cervical Expansive Laminoplasty}

\author{
Hiroki Yoshimatsu, Kensei Nagata, Hiroshi Goto, \\ Kimiaki Sato, and Noriyuki Ando \\ Department of Orthopaedic Surgery, Kurume University School of \\ Medicine, Kurume, Fukuoka, Japan
}

\begin{abstract}
We analyzed postoperative hematoma in cervical expansive laminoplasty, and examined 15 cases by ultrasound. Eight cases showed hematoma in the sutured area of cervical posterior muscles. All cases showed absorption of hematoma in 3 to 4 weeks. Ultrasound confirmed the presence, size, and depth of the hematoma.These results indicated that the start time of exercise to cervical posterior muscles was 3 to 4 weeks postoperatively.
\end{abstract}

Key words : expansive laminoplasty (脊柱管拡大術), cervical myelopathy (頚䯣症), ultrasound (超音波検查), hematoma (血腫), rehabilitation(リハビリテーション)

\section{はじめに}

頝椎脊柱管拡大術の高齢者の症例数増加 ${ }^{(5)}$ に伴い, 術後の早期離床が年々重要視されるようになってきた。 しかし, 術後に創離開が生じれば, 早期離床は難しく なり，ADL回復を妨げかねない。そこで今回，我々 は頚椎脊柱管拡大術を施行した症例に対し, 術後の縫 合部を超音波検査にて評価した。

\section{対象及び方法}

难椎棘突起縦割式脊柱管拡大術を施行した 15 症例 について超音波検査にて縫合部を評価した。評価時期 は術後 2 週, 3 週, 4 週とした. 男性 10 例, 女性 5 例であり，34〜85 歳（平均年歯：62.9歳）であった。 原因疾患は CSM が 8 例, OPLLによる脊䯣症が 6 例, 頝椎椎間板へルニアによる脊髄症が 1 例であった。
使用機種は Aloka 社製の SSD-500 で，探触子は $3.5 \mathrm{MHz}$ リニア型であった。測定断面は矢状断, 水 平断にて C $2 \sim \mathrm{C} 7$ の範囲とした。

術後の後療法は術当日がマジックベッド固定, 術翌 日〜オルソカラー装着にて坐位可, 術後 5 日目〜歩行 可とした.

\section{結果}

血腫形成は 8 例に認められた. 血腫の大きさは水平 断にて $1 \mathrm{~cm} \times 1 \mathrm{~cm}$ 以上（触診にて十分存在のわか る）が 2 例， $1 \mathrm{~cm} \times 1 \mathrm{~cm}$ 以下（触診にて不明瞭） が 6 例であった，大きな血腫を認めた 2 例はワーファ リン内服中の症例之, 自発的に縫合筋群への早期過負 荷を施行した症例であった。小さな血腫を認めた 6 例 は全て, 術後 2 週より血腫の減少を認め, 術後 3 週に 2 例が, 術後 4 週に 4 例が血腫消失していた. 


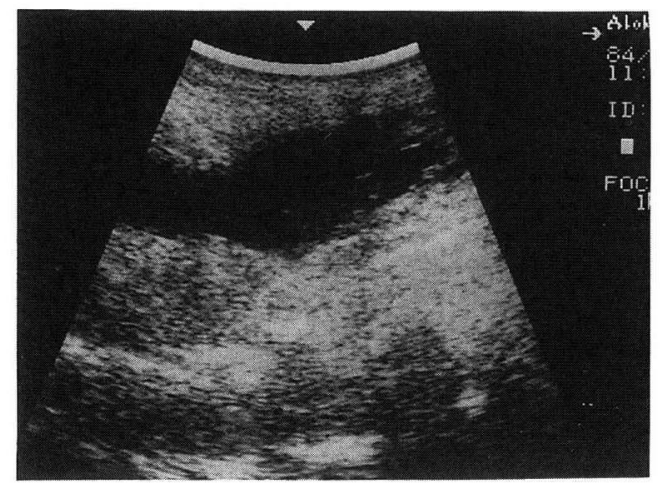

A- 1

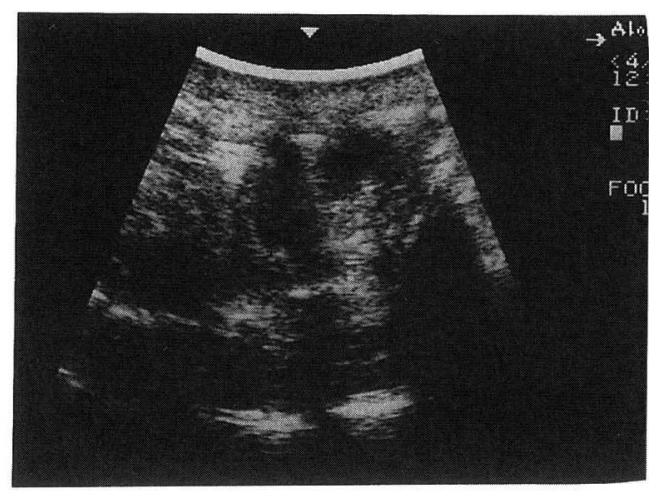

B- 1

図1 症例 1 (74 歳, 男性) $\begin{array}{ll}\mathrm{A}: \text { : 術後 } 2 \text { 週 } 1 \text {. 矢状断 }\left(\mathrm{C}_{5} \sim \mathrm{C}_{7} \text { 領域 }\right) & 2 \text {. 水平断 }\left(\mathrm{C}_{6} \text { 領域 }\right) \\ \mathrm{B}: \text { 術後 } 4 \text { 週 } 1 \text {. 矢状断 } \quad 2 \text {. 水平断 } & \end{array}$

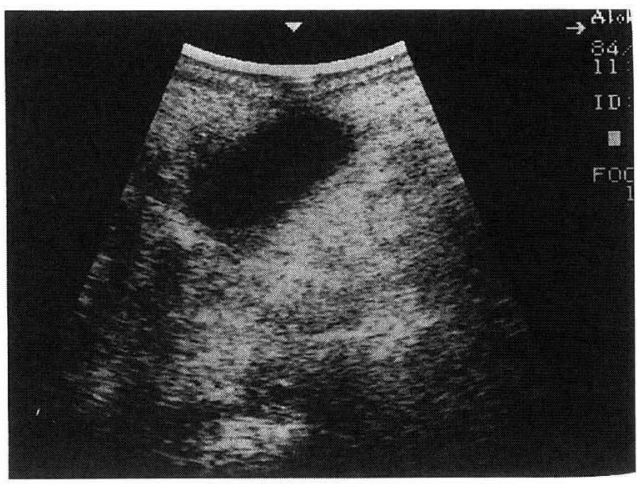

A- 2

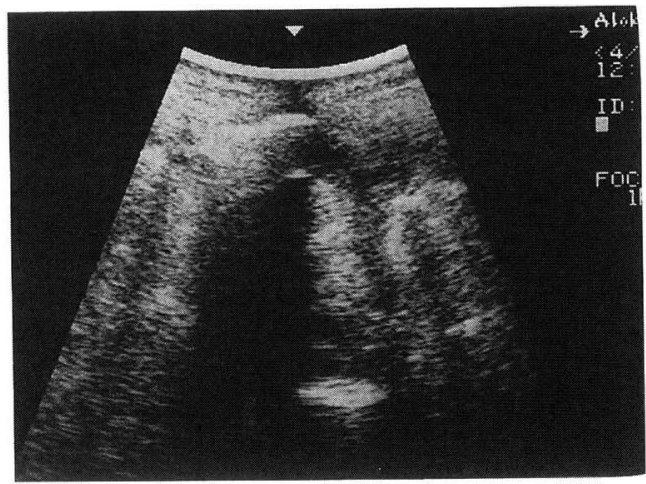

B- 2
血腫の位置は浅層が 3 例, 深層が 1 例, 共に存在す る屯のが 4 例であり，C 5 領域を中心に存在するもの が多かった。

\section{症 例 供 覧}

症例 1：74 才男性. CSM にて頚椎脊柱管拡大術施行 した症例である。既往歴に両下肢静脈瘤, 脳梗塞があ り，ワーファリン内服しているものの，凝固系は正常 であった。術後 2 週より, C 4-C 7 領域, 浅層に $2 \mathrm{~cm}$ $\times 2 \mathrm{~cm}$ の血腫を認めた。すぐに，ドレーン留置，ス カパラバンド装着を行い, 血腫の減少を認めた（図 1 ). 症例 2 ：70才女性. CSM にて手術施行. 既往歴に
DM，慢性腎不全があり，インシュリン注射を行っ ていた。術後 2 週では C 5 中心の浅層に, $0.3 \mathrm{~cm} \times$ $0.3 \mathrm{~cm}$ の血腫を認めたが, 術後 4 週でほぼ消失してい た（図 2).

\section{考察}

頚部脊柱管拡大術後の合併症には早期で，䯣節性麻 痺, 術後血腫, 早期以降で後弯変形, axial pain など

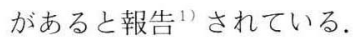

また, 頚椎の後方筋群には僧帽筋, 頭板状筋, 頭半 棘筋などがあり，何層あの筋肉がそれぞれ独自の働き をしている. 特に, 传柱管拡大術は頚椎後方要素を温 


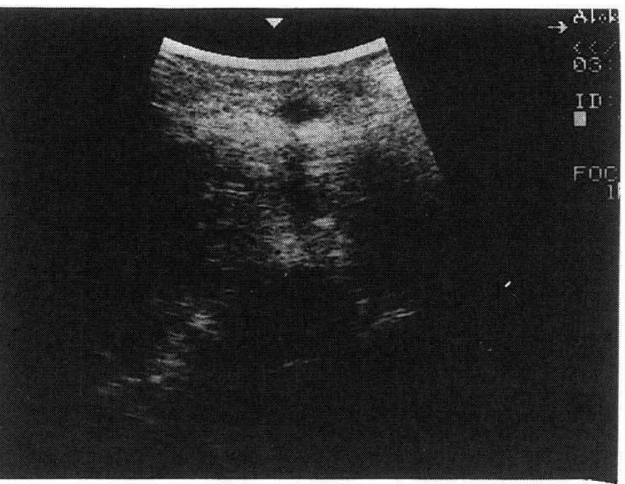

\section{A}

B

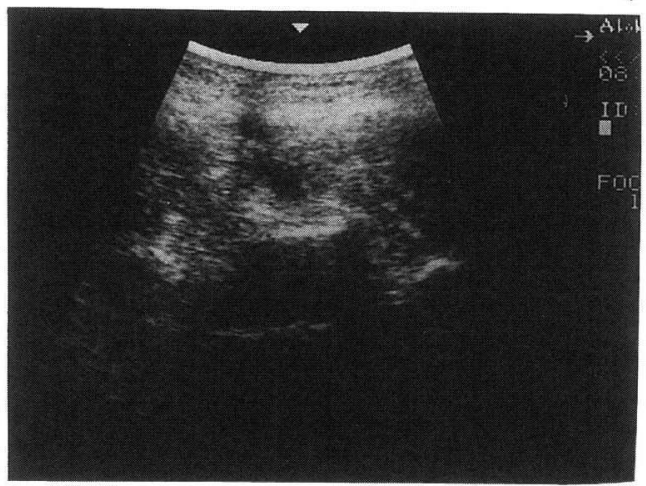

C

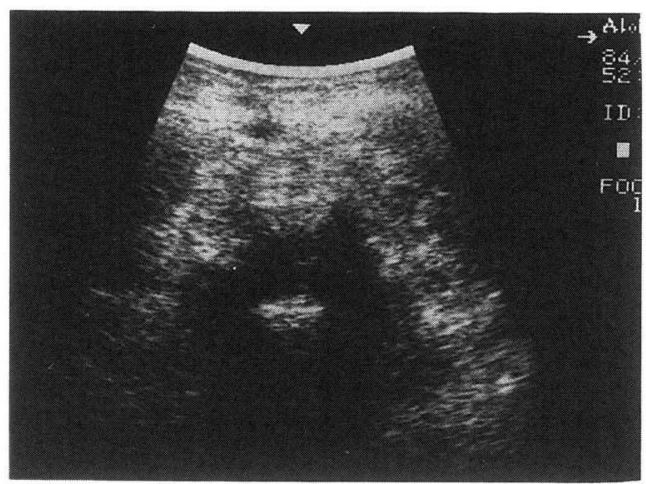

図 2 症例 2 (70歳, 女性) : 水平断; $\mathrm{C}_{5}$ 領域 A : 術後 2 週 B : 術後 3 週 C : 術後 4 週

存することが特徴であり, 展開あるいは縫合において 特別な注意が必要である。
一方, 超音波検查は整形外科では様々な疾患に利用 されており, 特に, 脊椎外科領域では術中診断として 使われている ${ }^{3)}$.

今回, 術後血腫評価に超音波検査を行ったが, 血腫 の有無, 大きさ，位置がわかることで，血腫に対する 治療方針を立てることができる, 縫合筋群への負荷を 行う運動の開始時期を決定する指標となりえると考え られた。

我々は術後血腫に対する治療方針として, 浅層に留 まるあのやサイズの小さいものに対して, 日常生活動 作の指導, 徹底を行い, 必要であれば, ドレーン留置, スカパラバンド装着などを行っている。 また, 深層に 及びかつ, 大きな血腫に対しては, 病巣掻爬, 二次縫 合老行い, 約 2 週間程度の長期的なドレーン留置とし ている.

さらに，血腫消失が術後 $3 \sim 4$ 週で生じていたこと より, 縫合筋群への負荷運動は創治癒後, 具体的には $3 \sim 4$ 週にて開始すべきであると推測される ${ }^{274)}$.

\section{結語}

頚椎脊柱管拡大術術後の 15 例について縫合部を超 音波検査にて検討した。血腫形成を 8 例に認めた。術 後血腫評価に打ける超音波検査は血腫に対する治療方 針, 縫合筋群への負荷を行う運動の開始時期を決定す る指標となり得た.

\section{参 考 文 献}

1) Hosono N, Yonenobu K, Ono K : Neck and Shoulder Pain After Laminoplasty. SPINE 21 (17) : 1969-1973, 1996.

2) 伊藤達雄 : 頝椎 en-bloc laminoplasty 後の早期運動 療法の効果, 理学診療, 6（3）：193-198, 1995.

3）望月真人：余椎外科に打ける超音波診断。 MB Orthop, 11 (5) : 187-193, 1998.

4）永田見生, 志波直人：頝部脊柱管拡大術（綐割法）と 後療法. 整形外科手術後療法のコッ (上), 全日本病院 出版会. 東京, pp.10-14, 2000.

5）吉松弘喜他：超高齢者（80 歳以上）の頝椎手術例の検 討. 西日本金椎研究会誌，27（1）：76-79，2001. 